\title{
EMPLOYER BRANDING ON SOCIAL MEDIA AND RECRUITMENT WEBSITES: SYMBOLIC TRAITS OF AN IDEAL EMPLOYER
}

\author{
Ludvík Eger, Michal Mičík, Petr Řehoř
}

\section{Introduction}

With some regional differences, employment levels in many developed economies are very high, and competition for skilled staff is intense. Competitive labour markets aside, competition for employees is likely to become an increasingly important issue as the population worldwide ages (Wilden, Gudergan, \& Lings, 2010). Employer branding has gained favour as a management tool over the last decade. Even as firms face global economic conditions that are both difficult to forecast and subject to extreme variance, the need to attract, retain and motivate staff remains (Moroko \& Uncles, 2009).

Attracting potential candidates is an important issue in the recruitment process. Organizations need to attain differentiation and become more competitive in attracting talented (Egerová, Lančarič, Eger, \& Savov, 2015) and especially young people through employer branding (EB) initiatives. Understanding what attracts talented recruits to a company may provide important insights for human resources managers (Alniacik, Alniacik, Erat, \& Akcin, 2014). Examining the attributes of employer brand is relevant for practitioners and researchers.

Attractiveness is revealed when young people seek the opportunity to participate in the selection process at a specific company.

This study seeks to gain an understanding of symbolic factors related to prospective applicants' initial attraction to a company as a place to work. First, we investigate how young people, business students in their final year at university, assess the personality traits of an ideal employer.

Second, we examine how these respondents use internet and especially company recruitment websites and company social media to gain information about their future employer.

\section{Employer Branding}

Brands are among a firm's most valuable assets and as a result brand management is a key activity in many firms. The application of branding principles to human resources management has been termed "employer branding". Employer branding represents a firm's efforts to promote, both within and outside the firm, a clear view of what makes it different and desirable as an employer (Backhaus \& Tikoo, 2004).

The concept of employer branding has recently become a prominent topic in the human resources management field (Alniacik et al., 2014). The term "employer brand" was first conceptualized by Ambler and Barrow (1996) in their pioneering paper. The concept of employer branding has emerged as a result of the application of marketing principles to human resources management.

Employer brand is defined as "the package of functional, economic and psychological benefits provided by employment, and identified in with the employing company" (Ambler \& Barrow, 1996, p. 17). These authors suggest that just like a consumer brand, an employer brand possesses a personality and an image in the mind of the labour market, which can create tight bonds between the brand and its workforce (Fernandez-Lores, Gavilan, Avello, \& Blasco, 2015).

Employer branding helps to retain talented individuals, build trust in leadership and develop stronger bonding ties through its impact on individual, team and organisational engagement (Alniacik et al., 2014; Gittel, Seidner, \& Wimbush, 2010). Favourable employer branding can reduce recruitment costs by improving recruitment performance (Barrow \& Mosley, 2005; Berthon, Ewing, \& Hah, 2005).

The brand must be able to differentiate, to create loyalty, to satisfy and establish an 
emotional connection with potential candidates (Davies, 2008). Thus, the value of a brand is associated with its degree of awareness/ recognition and the image it conveys to people, new potential candidates (Reis \& Braga, 2016). Preferences and motivation concerning work (also concerning the employer brand) may be different for each generation, and would require attention in human resources management practices in the recruitment process (Eger, Egerová, \& Mičík, 2015; Fernandez-Lores, Gavilan, Avello, \& Blasco, 2015).

Social media may play a key role in the recruitment process in terms of branding the organisation to potential employees (Sivertzen, Nilsen, \& Olafsen, 2013). The use of social media for organisations has benefits such as free, unlimited use and shorter response time with respect to contact and activities (Furu, 2011).

\subsection{Organizational Attractiveness}

Organizational attractiveness concerns the envisioned benefits that a potential employee sees in working for a specific organisation. The construct may be thought of as an antecedent of the more general concept of employer brand equity. In other words, the more attractively an employer is perceived by potential employees, the stronger that particular organisation's employer brand equity is (Berthon, Ewing, \& Hah, 2005).

Organisational attractiveness is regarded as a multidimensional construct. Berthon, Ewing and Hah (2005) developed and validated a multi-item scale to identify and operationalize the components of employer attractiveness. The authors identified five distinct dimensions of employer attractiveness. Their scale assesses to what extent the organization offers the following values: interest value, social value, economic value, development value and application value. Attractiveness has been operationalized through the attributes of attractiveness, the factors considered by potential candidates when choosing an employer (Berthon et al., 2005). Applicants prioritize these factors according to their respective needs and expectation.

According to Lievens and Highhouse (2003) we recognize instrumental and symbolic attributes, where the first refer to what the organization actually offers that is useful for job seekers (e.g., salary package). Researchers mainly focus on instrumental factors (Arrachchige \& Robertson, 2011; Berthon, Ewing, \& Hah, 2005; Sivertzen, Nilsen, \& Olafsen, 2013).

Symbolic attributes, in turn, represent subjective and intangible aspects, e.g., degree of business innovation, culture, prestige, etc. (Reis \& Braga, 2016).

Lievens (2007) used an instrumental symbolic framework to study factors relating to both employer image and organisational identity. This author proposed that organizational attractiveness depends not only on instrumental aspects of the job, but also on the symbolic meaning associated with joining a future employer. Symbolic attributes are linked to people's need to maintain their selfidentity, to enhance their self-image, or to express themselves (Aaker, 1997; Lievenes \& Highhouse, 2003). It is supposed that jobseekers search organizations that meet expectations (traits) which reflect their self-concept. And applicants tended to be especially attracted to employing organizations that had traits similar to their own traits (Tom, 1971; Kissel \& Büttgen, 2015).

Studies have shown that symbolic attributes may be especially relevant and can differentiate an employer from its competitors more than instrumental attributes (Lievens \& Highhouse, 2003; Srivastava \& Bhatnagar, 2010; Reis \& Braga, 2016).

Jobseekers have only basic information and vague knowledge and experience about job and organizational characteristics in the early stage of the recruitment process (Srivastava \& Bhatnagar, 2010). Lievens and Highhouse (2003) believe that the instrumental - symbolic framework of employer branding has several key applications in the area of applicants' initial attraction to companies. They argue that the importance of the symbolic functions of a brand increases when instrumental differences between brands are limited. These symbolic attributes describe the job/organization in terms of subjective and intangible attributes and could be important in attracting young people through websites and through communication with social media.

\subsection{Generation $Y$ and Employer Attractiveness}

Millennials (Generation $\mathrm{Y}$ ) believe that business needs to pay as much attention to people and purpose as it does to products and profit (Deloitte, 2015). Companies, especially in 
developed countries, will have to take action and make significant changes if they want to attract, acquire and retain employees of generation $\mathrm{Y}$. Greater interest in new technologies and their wish for fast career development are important characteristics of this generation (Tapscott, 2010; Caraher, 2015).

It is evident that the Internet has become one of the most popular sources of information for jobseekers (Backhaus, 2004; Soulez \& Soulez, 2011) and especially Millennials often evaluate companies through the Internet before they apply for a job; they want to be sure before they connect their professional lives with them. (Jobvite, 2013; Deloitte, 2015) The results of the study conducted by Deloitte (2015) indicate that Millennials expect leading companies to provide employees with opportunities for learning and personal growth. Generation $Y$ is often presented as preferring a positive work environment and stimulating work offering opportunities for advancement and success, encouraging a collective management style, and attentive to the work-life balance (Eisner, 2005). The literature is more contradictory concerning the expectations of generation $Y$ in terms of salary. For some researchers, salary is considered less important than other attributes, such as a fulfilling private life (Eisner, 2005), while for others this generation remains attentive to salary (Lowe, Levitt, \& Wilson, 2008; Qenani-Petrela, Schlosser, \& Pompa, 2007).

\section{Methodology}

Our research focuses on how young people, business students in their final year at university, assess the personality traits of an ideal employer, and on how young people use company web and recruitment websites and company social media to gain information about their future employer. Internet offers the opportunity to communicate the employer brand to potential candidates, to maintain effective interactions with potential applicants, and to successfully attract young people.

The research question is:

Which employer symbolic attractiveness is prioritized by Generation Y?

And the research sub-questions are:

- How do business students in their final year at university assess the chosen personality traits of an ideal employer?

- To what extent do business students use recruitment websites and company social media to gain information about their future employer?

To address the above-mentioned research questions, the following hypotheses are developed and tested in this study.

Hypothesis 1: Perceived importance of symbolic traits of employer attractiveness may vary according to respondent's gender.

Hypothesis 2: Perceived importance of symbolic traits of employer attractiveness may vary according to respondent's current employment status.

Hypothesis 3: HO: There is no difference between men and women in the assessment of the importance of an organization's profiles on social media.

HA: There is a difference between men and women in the assessment of the importance of an organization's profiles on social media.

Hypothesis 4: HO: There is no difference in the assessment of the importance of an organization's recruitment websites that offer job opportunities between men and women.

$H A$ : There is a difference between men and women in the assessment of the importance of an organization's recruitment websites that offer job opportunities.

Hypothesis 5: Respondents (business students) that follow information about job offers on an organization's social media profiles find the organization's profiles on social sites important.

Hypothesis 6: Respondents (business students) that follow information about job offers on recruitment websites find the organization's recruitment websites important.

Hypothesis 7: Respondents (business students) that find the organization's recruitment websites important also find the expression of the key organizational values important.

We examine the above-mentioned statements ( $\mathrm{H} 1$ and $\mathrm{H} 2)$ using descriptive statistics and semantic differentials which are suitable for this purpose. To test hypotheses $\mathrm{H} 3$ and $\mathrm{H} 4$ we used the non-parametric MannWhitney $U$ Test (a test of equal distributions). Variables in $\mathrm{H} 5, \mathrm{H} 6$ and $\mathrm{H} 7$ are displayed in PivotTable and then the Chi-Square Independence Test is used to compare whether the counts of the actual data for each unique combination of factors of the two variables are significantly different than the counts that would be expected if the attributes were totally independent of each other (Gray, 2009). 


\subsection{Sample}

The sample consisted of 259 final-year students at two regional universities in the Czech Republic and their faculties of economics (192 women and 67 men). The students were from 21 to 24 years old and 79 percent of the students had already worked part time during their studies. All the students completed a short internship as a part of their study program.

Data was collected by a self-administered questionnaire which includes demographic questions and consists of two main parts. In the first part, a semantic differential that measures the ideal brand personality of a typical employer is used. We needed a scale to measure human and employer brand personality with the accent on symbolic factors (traits). A semantic differential with ten items, developed by Kissel and Büttigen (2015), was a useful tool for this purpose. The authors integrated items from brand personality created by Aaker (1997), the organisational personality created by Lievens and Highhouse (2003) and some standard items from empirical social research that have been used for personality measurement (Fridrichs, 1990). Jobseekers, final-year business students, evaluated chosen symbolic traits of the ideal employer on a 7-point scale. Each component- trait is described by a pair of opposite adjectives. Respondents evaluate each item on a bipolar scale and can vary the position of the positive or negative adjectives.

The chosen traits (Tabs. 1-3) include broader factors such as: extroversion, conscientiousness, agreeableness, competence, sophistication or openness to experience and excitement (cf. fivefactor model, Soto, \& Jackson, 2013).

The semantic differential is a list of opposite adjective scales (the method was invented by Osgood, Suci and Tannenbaum (1957)). Initially, the semantic differential was developed to measure the connotative meaning of terms. These days, semantic differential scales are used in a variety of social science researches and also for marketing purposes. It is a very general measurement technique that has to be adapted to each research context, depending on the goals and aims of the study (Verhagen \& Meents, 2007; Hendl \& Remr, 2017). The semantic differential is a type of measurement in which the conclusions of the public regarding attitudes are deduced from statements on their opinions, views, feelings, behaviour, etc., to the object or category of object. It is especially suitable for measuring emotional and behavioural aspects of the attitude. Its great advantage is easy administration and relatively fast evaluation (Klement, Chráska, \& Chrásková, 2015).

The second part consists of a questionnaire with items focused on students' use of company recruitment websites and company social media to gain information about a prospective employer. This instrument was chosen because it had already been employed in a study by Sivertzen, Nilsen and Olafsen (2013) that also focused on employer attractiveness research. Respondents must evaluate each item in this part of questionnaire via a five-option Likert scale ( 1 = not important at all, $5=$ very important).

The piloting process of the questionnaire was performed on five students in order to check and adjust the understanding of the translated items and scale.

\section{Analyses and Results}

A total of 281 final-year students participated in this study by voluntarily filling out the questionnaire. After preliminary analyses, 22 questionnaires were eliminated due to missing responses. The remaining 259 questionnaires were coded and then analysed in Microsoft Excel.

The results of the first part of the conducted survey can be presented as a figure (semantic differential) where the average scores of each group of respondents are connected into one line. One of the most appealing aspects of the semantic differential scale is the ability of the researcher to compute averages and then plot a "profile" of the brand or company image (Burns, Veeck, \& Bush, 2017). The answer to the research sub-question is represented by a vertical "line of means" (view of selected group of respondents) that summarizes the average perception of the chosen symbolic traits of the ideal employer. Detailed information can be seen in Tabs. 1, 2 and 3. In our case, the semantic differential shows a profile of chosen symbolic traits of an ideal employer.

Before testing the research hypotheses nos. 3-7, we made some preliminary analyses for the second part of the questionnaire. Scale reliability was assessed by internal consistency using Crombach's Alpha coefficient (value 0.709 is acceptable).

In the conducted survey, the final semantic differentials show business students' semantic space according to the symbolic traits of an 


\section{Marketing a obchod}

ideal employer. The chosen adjectives are used as personality descriptors (traits) of an ideal employer.
As can be seen from Fig. 1 and Tab. 1, the perceived importance of the symbolic traits of employer attractiveness is similar according
Exciting

Playful

Generous

Flexible

Reliable

Innovative

Professional

Modern

Chaotic

Liberal

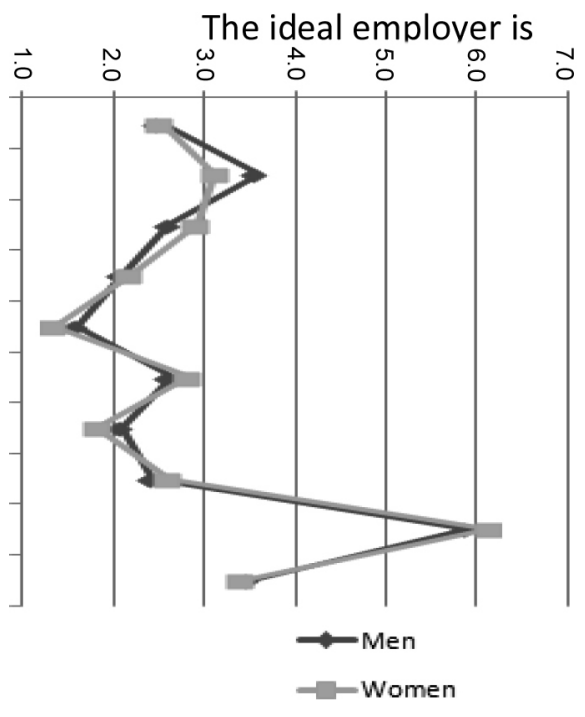

Boring

Serious

Thrifty

Inflexible

Unreliable

Traditional

Unprofessional

Classic

Organized

Strict

\section{Tab. 1:}

Symbolic personality traits of ideal employer (gender)

The ideal employer is (gender)

\begin{tabular}{l|c|c|l}
\hline \multicolumn{1}{c|}{ Item } & Men & Women & \\
\hline Exciting & 2.5 & 2.5 & Boring \\
\hline Playful & 3.6 & 3.1 & Serious \\
\hline Generous & 2.6 & 2.9 & Thrifty \\
\hline Flexible & 2.1 & 2.2 & Inflexible \\
\hline Reliable & 1.6 & 1.4 & Unreliable \\
\hline Innovative & 2.6 & 2.8 & Traditional \\
\hline Professional & 2.1 & 1.8 & Unprofessional \\
\hline Modern & 2.4 & 2.6 & Classic \\
\hline Chaotic & 5.9 & 6.2 & Organized \\
\hline Liberal & 3.5 & 3.4 & Strict \\
\hline Number of students & 67 & 192 & \\
\hline
\end{tabular}




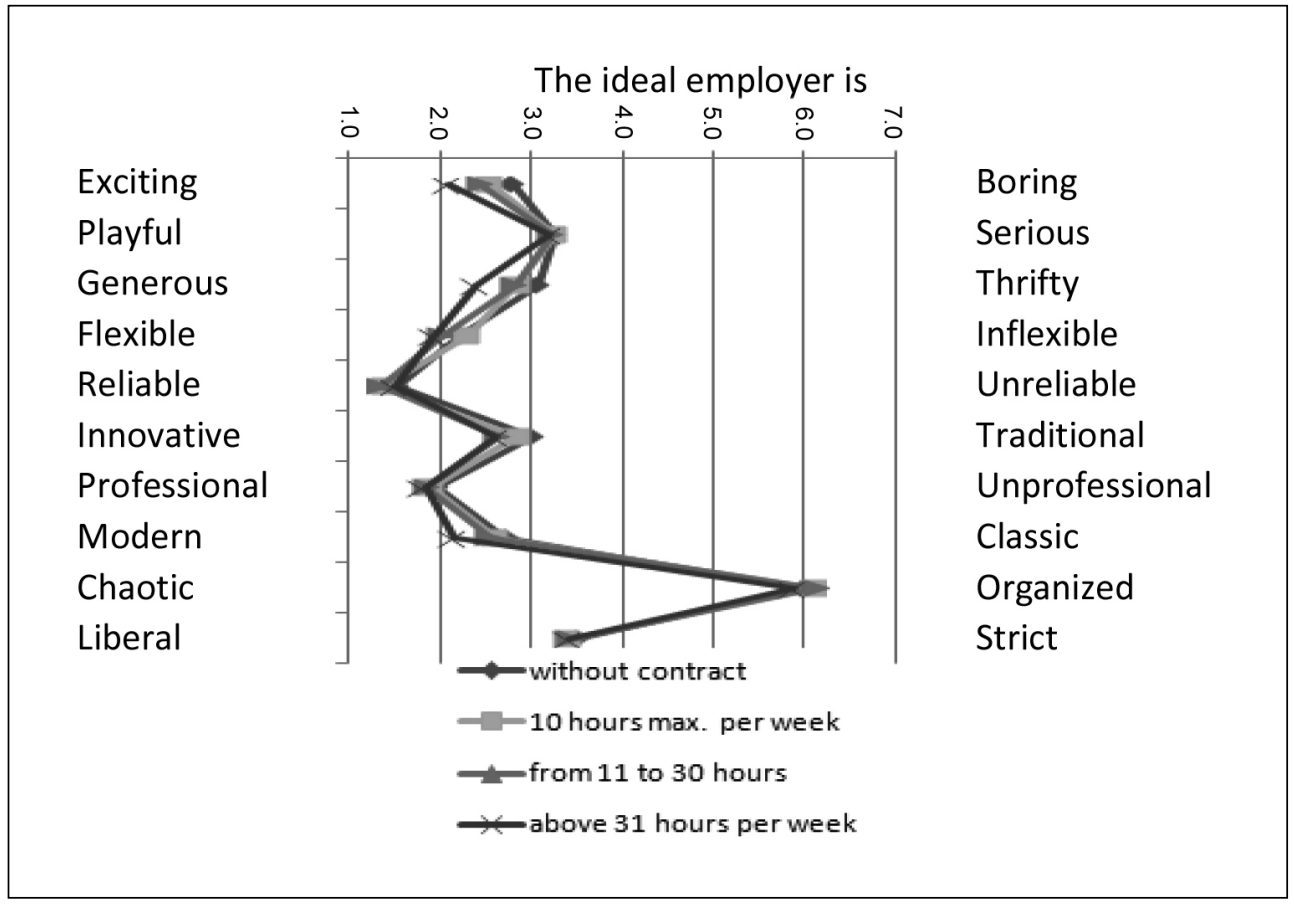

\section{Tab. 2: Symbolic personality traits of ideal employer (current employment status)}

\begin{tabular}{l|c|c|c|c|l}
\multicolumn{1}{c|}{ Item } & $\begin{array}{c}\text { The ideal employer is (current employment status) } \\
\text { without } \\
\text { contract }\end{array}$ & $\begin{array}{c}\mathbf{1 0} \text { hours } \\
\text { max. per } \\
\text { week }\end{array}$ & $\begin{array}{c}\text { from 11 } \\
\text { to } \mathbf{3 0} \text { hours }\end{array}$ & $\begin{array}{c}\text { over 31 } \\
\text { hours per } \\
\text { week }\end{array}$ & \\
\hline Exciting & 2.8 & 2.6 & 2.5 & 2.1 & Boring \\
\hline Playful & 3.3 & 3.3 & 3.2 & 3.2 & Serious \\
\hline Generous & 3.1 & 2.8 & 2.8 & 2.4 & Thrifty \\
\hline Flexible & 2.2 & 2.3 & 2.0 & 1.9 & Inflexible \\
\hline Reliable & 1.5 & 1.4 & 1.4 & 1.5 & Unreliable \\
\hline Innovative & 3.0 & 2.8 & 2.7 & 2.6 & Traditional \\
\hline Professional & 2.0 & 1.9 & 1.9 & 1.8 & Unprofessional \\
\hline Modern & 2.7 & 2.6 & 2.6 & 2.2 & Classic \\
\hline Chaotic & 6.0 & 6.1 & 6.2 & 5.9 & Organized \\
\hline Liberal & 3.5 & 3.4 & 3.5 & 3.4 & Strict \\
\hline Number of students & 55 & 85 & 100 & 19 & \\
\hline
\end{tabular}




\section{Marketing a obchod}

Tab. 3: Symbolic personality traits of ideal employer (study results)

The ideal employer is (study results)

\begin{tabular}{l|l|l|l}
\hline \multicolumn{1}{c|}{ Item } & A,B & C,D & \\
\hline Exciting & 2.5 & 2.6 & Boring \\
\hline Playful & 3.1 & 3.4 & Serious \\
\hline Generous & 2.8 & 2.9 & Thrifty \\
\hline Flexible & 2.1 & 2.2 & Inflexible \\
\hline Reliable & 1.4 & 1.4 & Unreliable \\
\hline Innovative & 2.7 & 2.9 & Traditional \\
\hline Professional & 1.9 & 1.9 & Unprofessional \\
\hline Modern & 2.5 & 2.7 & Classic \\
\hline Chaotic & 6.1 & 6.1 & Organized \\
\hline Liberal & 3.3 & 3.6 & Strict \\
\hline Number of students & 151 & 108 & \\
\hline
\end{tabular}

Exciting

Playful

Generous

Flexible

Reliable

Innovative

Professional

Modern

Chaotic

Liberal

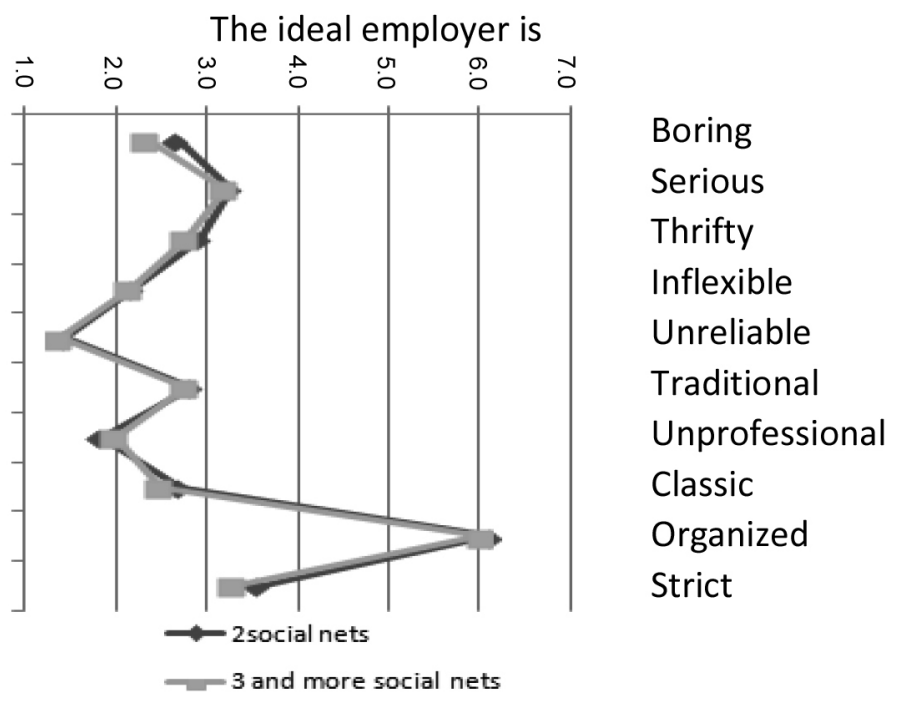


to the respondent's gender. This means that hypothesis no. 1 is not supported. Important symbolic personality traits of an ideal employer for both genders can be described as: reliable, professional, flexible and organized.

Fig. 2 and Tab. 2 show that the perceived importance of the symbolic traits of employer attractiveness is similar according to the respondent's current employment status. This means that hypothesis no. 2 is not supported and again, very important symbolic traits are: reliable, professional and organized.

We can summarize that for business students the most important symbolic traits of their future employers can be described as: reliable, professional and organized, and these traits are independent of the student's gender, current employment status and even their study results (Tab. 3).

Fig. 3 shows that the perceived importance of the symbolic traits of employer attractiveness is similar according to the respondent's number of social media profiles.
To summarize the findings from Figs. $1-3$, the scores of each group of respondents are connected into similar lines. The overall semantic differential for all three cases is almost the same. This means that it is independent of the respondent's gender, employment status and number of social media profiles.

As can be seen from Tab. 4, 53\% of respondents find recruitment websites that offer job opportunities important (scale 4 and 5 of the items) and the same number of respondents agree with the statement: the organization's recruitment websites give me detailed information about their job opportunities. For $50 \%$ of respondents the key organization values presented on both recruitment websites and social media sites are important. It is also evident from the table that only $26 \%$ of respondents find the organization's profiles on social sites important and only $18 \%$ of respondents state that the organization's profiles on social media give them sufficient information about their job opportunities.

\section{Tab. 4: Results: company social media and recruitment websites}

\section{Questionnaire, part 2: company social media and recruitment websites}

\begin{tabular}{l|c|c|c|c|c|c|c}
\hline \multicolumn{1}{c|}{ Items } & $\mathbf{1}$ & $\mathbf{2}$ & $\mathbf{3}$ & $\mathbf{4}$ & $\mathbf{5}$ & Mean & SD \\
\hline $\begin{array}{l}\text { I follow information about job offers on the } \\
\text { organization's social media profiles }\end{array}$ & 13 & 86 & 47 & 103 & 10 & 3.04 & 1.041 \\
\hline $\begin{array}{l}\text { I follow information about job offers on the } \\
\text { organization's recruitment websites }\end{array}$ & 24 & 93 & 60 & 79 & 3 & 2.78 & 1.017 \\
\hline $\begin{array}{l}\text { I follow information about job offers on } \\
\text { social media sites outside the organization's } \\
\text { officialchannels }\end{array}$ & 31 & 81 & 50 & 87 & 10 & 2.86 & 1.124 \\
\hline $\begin{array}{l}\text { I find the organization's profiles on social sites } \\
\text { important }\end{array}$ & 27 & 77 & 87 & 64 & 4 & 2.77 & 0.986 \\
\hline $\begin{array}{l}\text { I agree with statement: the organization's } \\
\text { profiles on social media give me detailed } \\
\text { information about their job opportunities }\end{array}$ & 21 & 98 & 93 & 44 & 3 & 2.65 & 0.893 \\
\hline $\begin{array}{l}\text { I find recruitment websites that offer job } \\
\text { opportunities important }\end{array}$ & 8 & 35 & 78 & 117 & 21 & 3.42 & 0.928 \\
\hline $\begin{array}{l}\text { I agree with statement: the organization's } \\
\text { recruitment websites give me detailed } \\
\text { information about their job opportunities }\end{array}$ & 2 & 39 & 80 & 125 & 13 & 3.42 & 0.831 \\
\hline $\begin{array}{l}\text { Expression of the key organization values } \\
\text { (both on recruitment websites and social } \\
\text { media sites) is important to me }\end{array}$ & 6 & 36 & 88 & 116 & 13 & 3.36 & 0.865 \\
\hline
\end{tabular}




\section{Marketing a obchod}

Hypothesis 3: HO: There is no difference between men and women in the assessment of the importance of an organization's profiles on social media.

To test whether there was a statistically significant difference between the two groups of respondents in terms of their assessment of the importance of an organization's profiles on social media, we used a statistical nonparametric approach, the Mann-Whitney U-test. Following the Mann-Whitney results (Z-Score $=-0.917, \mathrm{p}$-value $=0.358<0.05$ ), we accepted Hypothesis $3 \mathrm{H0}$, which indicates that there is no significant difference between men and women.

Hypothesis 4: $\mathrm{H} 0$ : There is no difference between men and women in the assessment of the importance of an organization's recruitment websites that offer job opportunities.

To test whether there was a statistically significant difference between the two groups of respondents in terms of their assessment of the importance of an organization's recruitment websites that offer job opportunities, we again used a statistical non-parametric approach, the Mann-Whitney U-test. Following the MannWhitney results $(Z-S c o r e=-0.381, p$-value $=$ $0.704<0.05$ ), we accepted Hypothesis $4 \mathrm{H0}$, which indicates that there is no significant difference between men and women.

Hypothesis 5: Respondents (business students) that follow information about job offers on an organization's social media profiles find the organization's profiles on social sites important.

To determine whether there was a significant difference between the observed and expected frequencies of the two variables presented in cross-tabulation, a chi-squared test was conducted. In order to meet the basic condition of the chi-square test saying that no more than $20 \%$ of the expected counts are less

\section{Tab. 5: Job offers on organization's social media profiles}

\begin{tabular}{c|c|c|c|c|c}
\hline \multirow{2}{*}{$\begin{array}{c}\text { I follow information about job } \\
\text { offers on an organization's } \\
\text { social media profiles }\end{array}$} & \multicolumn{5}{|c|}{ I find organization's profiles on social sites important } \\
\cline { 2 - 6 } & $\mathbf{1}$ & $\mathbf{2}$ & $\mathbf{3}$ & $\mathbf{4}$ & $\mathbf{5}$ \\
\hline $\mathbf{1}$ & 1 & 0 & 0 & 0 & 1 \\
\hline $\mathbf{2}$ & 4 & 14 & 8 & 11 & 37 \\
\hline $\mathbf{3}$ & 1 & 8 & 8 & 6 & 23 \\
\hline $\mathbf{4}$ & 5 & 14 & 20 & 17 & 56 \\
\hline $\mathbf{5}$ & 0 & 1 & 4 & 3 & 9 \\
\hline Sum & 11 & 37 & 40 & 37 & 126 \\
\hline
\end{tabular}

\section{Tab. 6: Job offers on recruitment websites}

\begin{tabular}{c|c|c|c|c|c} 
I follow information about job & \multicolumn{5}{|c}{ I find recruitment websites that offer job opportunities important } \\
\cline { 2 - 6 } $\begin{array}{c}\text { offers on an organization's } \\
\text { recruitment websites }\end{array}$ & $\mathbf{1}$ & $\mathbf{2}$ & $\mathbf{3}$ & $\mathbf{4}$ & $\mathbf{5}$ \\
\hline $\mathbf{1}$ & 6 & 6 & 6 & 3 & 3 \\
\hline $\mathbf{2}$ & 2 & 20 & 33 & 32 & 6 \\
\hline $\mathbf{3}$ & 0 & 4 & 23 & 29 & 4 \\
\hline $\mathbf{4}$ & 0 & 5 & 15 & 51 & 8 \\
\hline $\mathbf{5}$ & 0 & 0 & 1 & 2 & 0 \\
\hline Sum & 8 & 35 & 78 & 117 & 21 \\
\hline
\end{tabular}




\section{Tab. 7: Organization's recruitment websites and key organizational values}

\begin{tabular}{c|c|c|c|c|c}
\multirow{2}{*}{$\begin{array}{c}\text { I find recruitment websites } \\
\text { that offer job opportunities } \\
\text { important }\end{array}$} & \multicolumn{6}{|c}{$\begin{array}{c}\text { Expression of the key organizational values (both on recruitment } \\
\text { websites and social media sites) is important to me }\end{array}$} \\
\cline { 2 - 6 } & $\mathbf{1}$ & $\mathbf{2}$ & $\mathbf{3}$ & $\mathbf{4}$ & $\mathbf{5}$ \\
\hline $\mathbf{1}$ & 1 & 3 & 2 & 2 & 0 \\
\hline $\mathbf{2}$ & 4 & 7 & 15 & 9 & 0 \\
\hline $\mathbf{3}$ & 0 & 12 & 30 & 34 & 2 \\
\hline $\mathbf{4}$ & 1 & 14 & 38 & 56 & 8 \\
\hline $\mathbf{5}$ & 0 & 0 & 3 & 15 & 3 \\
\hline Sum & 6 & 36 & 88 & 116 & 13 \\
\hline
\end{tabular}

Source: own

than 5 and all individual expected counts are 1 or greater (Yates, Moore, \& McCabe, 1999, p. 734), cells were pooled into fewer categories in a meaningful way to reduce the number of expected frequencies that are less than 5 . The calculated value of $\chi 2=5.556$ was lower than the critical value $\chi_{0,05}^{2}(9)=16.919$. This indicates that there is no significant relationship between the two variables. Hypothesis $5 \mathrm{HO}$ was therefore accepted and we can conclude: respondents that follow information about job offers on an organization's social media profiles don't find the organization's profiles on social sites important (Tab. 5).

Hypothesis 6: Respondents (business students) that follow information about job offers on recruitment websites find an organization's recruitment websites important.

The calculated value of $\chi^{2}=49.835$ was higher than the critical value $\chi_{0.05}^{2}(9)=16.919$. This indicates that there is a significant relationship between the two variables. Hypothesis $6 \mathrm{HO}$ was therefore not accepted. The value of Cramer's $V$ is 0.2532 which indicates a moderate association between the variables. This means that respondents who follow information about job offers on an organization's recruitment websites find the organization's profiles on social sites important (Tab. 6).

Hypothesis 7: Respondents (business students) that find an organization's recruitment websites important also find expression of the key organizational values important.

The calculated value of $\chi 2=25.689$ was higher than the critical value $\chi_{0.05}^{2}(9)=16.919$. This indicates that there is a relationship between the two variables, however, the association between the variables is very weak. Logically we conclude that the relationship between the two above mentioned variables is not significant (Tab. 7).

\section{Conclusion and Discussion}

Examining the attributes of an employer brand is relevant for practitioners and researchers. In this survey, we investigated employer symbolic attractiveness. The first part of our research survey focused on students' perceptions of chosen personality traits of an ideal employer. The second part of the conducted survey was students' assessment of company recruitment websites and company social media.

First, the results of symbolic attributes presented in semantic differentials and Tabs. 1-3 and Figs. 1-3 show how young people perceive the symbolic meaning of an ideal employer. As we mentioned above, jobseekers only have basic information and vague knowledge and experience about a job and organizational characteristics in the early stage of the recruitment process (Lievens \& Highhouse, 2003). The importance of symbolic functions of a brand increases in situations when instrumental differences between brands are limited, e.g., recruitment processes. The results showed that the most important symbolic personality traits that describe an ideal employer were: reliable, professional, flexible and organized. This analysis enabled us to identify which symbolic traits were prioritized by respondents - i.e., whether some traits were perceived as being more or less important than others. There is a possibility to highlight symbolic characteristics = symbolic attractiveness of an employer brand that has 
high value from the viewpoint of Generation $Y$ (here business students at university).

Second, the study contributes to research on employer branding and presents how young people use recruitment websites and company social media to search for a potential employer. Specifically, the findings show that there are no differences between men and women in the assessment of the importance of an organization's profiles on social media and on recruitment websites ( $\mathrm{H} 3$ and $\mathrm{H} 4)$. While respondents that follow information about job offers on an organization's recruitment websites find the organization's profiles on social sites important $(\mathrm{H} 6)$, respondents that follow information about job offers on an organization's social media profiles don't find the organization's profiles on social sites important (H5). This fact about social media importance does not support findings by Sivertzen, Nielsen and Olafsen (2013) who indicate that the use of social media in employer branding campaigns can be helpful in building a good reputation. We assume this fact calls for further research and probably for an intercultural comparison.

In relation to managers and $H R$ professionals, the results of the present study indicate several suggestions. First, a focus on employer branding campaigns and recruiting activities should be used not only towards instrumental attractiveness of an employer but also towards symbolic traits of an ideal employer to effectively communicate with Generation Y. This involves innovation opportunities especially for inbound marketing on recruitment websites and social media. Second, the results underline factors which are important in building a positive reputation of an organization and which can enhance intentions in potential candidates to apply for a job (cf. Sivertzen, Nilsen, \& Olafsen, 2013; Smith, 2011; Willimason et al., 2010). Employer branding is a relatively new approach to recruiting and retaining the best possible human talent within an employment environment that is becoming increasingly competitive. The employer branding concept can be especially valuable in the search for an organizing Framework for strategic human resources management (Backhaus \& Tikoo, 2004).

As organisations seek both to attract new employees and retain existing staff, employment advertising and employment branding will grow in importance. This can only be done effectively once organisations understand the factors contributing toward organizational attractiveness (Berthon, Ewing, \& Hah, 2005).

By building a strong employer brand, an organization can easily fall into the consideration of prospective employees, especially first-time jobseekers (Srivastava \& Bhatnagar, 2010).

\section{Limitations and further research}

The present research has limitations. Business students in their final year at two universities in the Czech Republic were chosen as respondents for this survey because they are attractive in the labour market. Due to the character of research sample, however, the results decrease the possibility to generalize. On the other hand, these representatives of Generation $Y$ use internet to find a future employer (Deloitte, 2015) and organizations often direct their recruitment efforts towards students. Also, the scope and depth of discussion is compromised because it is compared only to the selected research surveys.

These results contribute to the existing research on organizational attractiveness. Future studies may develop the scale by adding more symbolic personality traits and by testing these findings with other factors of the employer brand (Berthon, Ewing, \& Hah, 2005). Further research should focus on intercultural differences, which would show differences among generation $Y$ in various states in the world. Finally, a combination of other different methods could be used in further research to better and more deeply understand employer branding.

\section{References}

Aaker, L. J. (1997). Dimensions of Brand Personality. Journal of Marketing Research, 34(3), 347-356. https://dx.doi. org/10.2307/3151897.

Alniacik, E., Alniacik, Ü., Erat, S., \& Akcin, K. (2014). Attracting Talented Employees to the Company: Do We Need Different Employer Branding Strategies in Different Cultures? Procedia - Social and Behavioral Sciences, 150, 336-334. https://dx.doi.org/10.1016/j. sbspro.2014.09.074.

Ambler, T., \& Barrow, S. (1996). The Employer Brand. Journal of Brand Management, 4(3), 185-206. https://dx.doi.org/10.1057/ bm.1996.42.

Arrachchige, B., \& Robertson, A. (2011). Business students perceptions of a preferred 
employer: a study identifying determinants of employer branding. The UIP Journal of Brand Management, 8(3), 25-46.

Backhaus, K. B. (2004). An exploration of corporate recruitment descriptions on Monster.com. Journal of Business Communication, 41(2), 115-136. https://dx.doi. org/10.1177/0021943603259585.

Backhaus, K., \& Tikoo, S. (2004). Conceptualizing and researching employer branding. Career Development International, 9(5), 501-517. https://dx.doi. org/10.1108/13620430410550754.

Barrow, S., \& Mosley, R. (2005). The Employer Brand: Bringing the Best of Brand Management to People at Work. West Sussex: John Wiley and Sons.

Berthon, P., Ewing, M., \& Hah, L. L. (2005). Captivating company: dimensions of attractiveness in employer branding. International Journal of Advertising, 24(2), 151-172.

Burns, C. A., Veeck, A., \& Bush, F. R. (2017). Marketing Research. Harlow: Pearson Education Limited.

Caraher, L. (2015). Milenials \& Management. The Essential Guide to Making It Work at Work. Brookline: Bibliomotion.

Davies, G. (2008). Employer branding and its influence on managers. European Journal of Marketing, 42(5/6), 667-681. https://dx.doi. org/10.1108/03090560810862570.

Deloitte. (2015). Mind the gaps. The 2015 Deloitte Millenial survey. Retrieved May 1, 2015, from http://www2.deloitte.com/global/en/ pages/about-deloitte/articles/millennialsurvey. html.

Eger, L., Egerová, D., \& Mičík, M. (2015). Is the generation $Y$ looking for the employer with higher purpose? In Corporate social responsibility and human resource management in V4 countries (pp. 66-175). Nitra: Slovak University of Agriculture.

Egerová, D., Lančarič, D., Eger, L., \& Savov, R. (2015). Perspectives of talent management: Evidence from Czech and Slovak business organisations. E\&M Ekonomie a Management, 18(4), 108-120. https://dx.doi.org/10.15240/ tul/001/2015-4-008.

Eisner, S. P. (2005). Managing generation Y. S.A.M. Advanced Management Journal, 70(4), 4-15.

Fernandez-Lores, S., Gavilan, D., Avello, M., \& Blasco, F. (2016). Affective commitment to the employer brand: Development and validation of a scale. BRQ Business Research Quarterly, 19(1), 40-54. https://dx.doi. org/10.1016/j.brq.2015.06.001.

Fridrichs, J. (1990). Methoden empirischer Sozialforschung (14th ed.). Opladen: Westdeutscher Verlag.

Furu, N. (2011). The best heads are online. Personal og ledelse, 4, 32-35.

Gittel, J. H., Seidner, R., \& Wimbush, J. (2010). A Rational Model of High Performance Work Sytems Work. Organization Science, 21(2), 490-506. https://dx.doi.org/10.1287/ orsc. 1090.0446 .

Gray, E. D. (2009). Doing Research in the Real Word. London: SAGE.

Hendl, J., \& Remr, J. (2017). Metody výzkumu a evaluace. Praha: Portál.

Jobvite. (2015). The 2015 Jobvite Recruiter Nation Survey. Retrieved July 5, 2016, from http://www.jobvite.com/wpcontent/uploads/2015/09/jobvite_recruiter_ nation_2015.pdf.

Kausel, E. E., \& Slaughter, E. J. (2011). Narrow personality traits and organizational attraction: Evidence for the complementary hypothesis. Organizational Behavior and Human Decision Processes, 114(1), 3-14. https://dx.doi.org/10.1016/j.obhdp.2010.08.002.

Kissel, P., \& Büttgen, M. (2015). Using social media to communicate employer brand identity: The impact on corporate image and employer attractiveness. Journal of Brand Management, 22(9), 755-777. https://dx.doi. org/10.1057/bm.2015.42.

Klement, M., Chráska, M., \& Chrásková, M. (2015). The use of semantic differential method identifying the opinions of university students on education realized through e-learning. Procedia - Social and Behavioral Sciences, 186, 1214-1223. https://dx.doi.org/10.1016/j. sbspro.2015.04.165.

Lievens, F. (2007). Employer branding in the Belgian army. The importance of instrumental and symbolic beliefs for potential applicants, actual applicants and military employees. Human Resource Management, 46(1), 51-69. https://dx.doi.org/10.1002/hrm.20145.

Lievens, F., \& Highhouse, S. (2003). The Relation of Instrumental and Symbolic Attributes to a Company's Attractiveness as an Employer. Personnel Psychology, 56(1), 75-102. https://dx.doi.org/10.1111/j.1744-6570.2003. tb00144.x. 
Lowe, D., Levitt, K. J., \& Wilson, T. (2008). Solutions for retaining generation $Y$ employees in the workplace. Business Renaissance Quarterly, 3(3), 43-58.

Moroko, L., \& Uncles, M. D. (2009). Employer branding and market segmentation. Journal of Brand Management, 17(3), 181-196. https://dx.doi.org/10.1057/bm.2009.10.

Osgood, C. E., Suci, G. J., \& Tannenbaum, P. (1957). The Measurement of Meaning. Urbana, IL: University of Illinois Press.

Qenani-Petrela, E., Schlosser, J., \& Pompa, R. (2007). Satisfied employees are worth their weight in gold: What motivates generation Y? Journal of Food Distribution Research, 38(1), 113-118.

Reis, G. G., \& Braga, M. B. (2016). Employer attractiveness from a generational perspective: Implications for employer branding. Revista de Administração, 51(1), 103-116. https://dx.doi. org/10.5700/rausp1226.

Sivertzen, A. M., Nilsen, E., \& Olafsen, H. A. (2013). Employer branding: Employer attractiveness and the use of social media. Journal of Product \& Brand Management, 22(7), 473-483. https://dx.doi.org/10.1108/ JPBM-09-2013-0393.

Smith, T. K. (2011). Digital marketing strategies that Millenials find appealing, motivating, or just annoying. Journal of Strategic Marketing, 19(6), 489-499. https://dx.doi.org/ 10.1080/0965254X.2011.581383.

Soto, C. J., \& Jackson, J. J. (2013). Fivefactor model of personality. In D. S. Dunn (Ed.), Oxford Bibliographies in Psychology. New York, NY: Oxford University Press. https://dx.doi. org/10.1093/obo/9780199828340-0120.

Soulez, S., \& Guillot-Soulez, C. (2011). Recruitment marketing and generational segmentation: a critical analysis based on a sub-segment of Generation Y. Recherche et Applications en Marketing, 26(1), 39-55. https:// dx.doi.org/10.1177/205157071102600104.

Srivastava, P., \& Bhatnagar, J. (2010). Employer brand for talent acquisition: An exploration towards its measurement. Journal of Business Perspective, 14(1/2), 25-34. https://dx.doi.org/10.1177/097226291001400103.
Tapscott, D. (2010). Grown up digital: How the next generation is changing your world. New York: McGraw-Hill.

Tom, V. R. (1971). The role of personality and organisational images in the recruiting process. Organizational Behavior and Human Decision Procesess, 6(5), 573-592. https:// dx.doi.org/10.1016/S0030-5073(71)80008-9

Verhagen, T., \& Meents, S. (2007). A framework for developing semantic differentials in IS Research: Assessing the meaning of electronic marketplace quality. Serie Research Memoranda, VU Amsterdam University, 16.

Wilden, R., Gudergan, S., \& Lings, I. (2010). Employer Branding: Strategic implications for Staff Recruitment. Journal of Maketing Management, 26(1-2), 56-73. https://dx.doi. org/10.1080/02672570903577091.

Williamson, O. I., King., E. J., Lepak, D., \& Sarma, A. (2010). Firm reputation websites, and attracting applicants. Human resource management, 49(4), 669-687. https://dx.doi. org/10.1002/hrm.20379.

Yates, D., Moore, D., \& McCabe, G. (1999). The Practice of Statistics. New York: W.H. Freeman.

doc. PaedDr. Ludvík Eger, CSc. University of West Bohemia Faculty of Economics

Department of Marketing, Trade and Services

Czech Republic leger@kmo.zcu.cz

Ing. Michal Mičík University of West Bohemia

Faculty of Economics

Department of Marketing, Trade and Services

Czech Republic

micikm@kmo.zcu.cz

doc. Ing. Petr Řehoř, Ph.D. University of South Bohemia

Faculty of Economics

Department of Management Czech Republic rehor@ef.jcu.cz 


\title{
Abstract
}

\section{EMPLOYER BRANDING ON SOCIAL MEDIA AND RECRUITMENT WEBSITES: SYMBOLIC TRAITS OF AN IDEAL EMPLOYER}

\author{
Ludvík Eger, Michal Mičík, Petr Řehoř
}

In recent years, the employer brand has become an important source of a sustainable competitive advantage. There is increasing evidence that employers need to place greater emphasis on communication with talented young people. Jobseekers usually have only basic information and vague knowledge and experience about a job and organizational characteristics in the early stage of the recruitment process, and in this situation the symbolic functions of a brand are significant. Nowadays, prospective applicants search for information about future employers by using their recruitment websites and social media. The study identifies the significant factors (symbolic traits) which attract Czech university business students to choose their potential employers. The study also contains a survey which investigates the use of social media and recruitment websites in relation to the employer brand, including perceptions of an ideal employer. The study brings results about symbolic employer attributes, which are presented in semantic differentials and contribute to research on employer branding by presenting how young people use recruitment websites and company social media to search for a potential employer. The findings of the conducted study suggest that chosen symbolic traits of an ideal employer are similar in the respondents and are independent of gender and employment status. According to the findings regarding social media and recruitment websites, respondents that follow information about job offers on an organization's social media profiles don't find the organization's profiles on social sites important, whereas respondents that follow information about job offers on an organization's recruitment websites find the organization's profiles on social sites important. The paper concludes with theoretical and practical implications followed by directions for future research.

Key Words: Employer branding, HR management, symbolic traits, semantic differential, recruitment websites, social media, business student perceptions.

JEL Classification: M1, M3, D83.

DOI: 10.15240/tul/001/2018-1-015 